\title{
Effectiveness of Cryopreservation in Patients of Young Reproductive Age with the Risk of Ovarian Hyperstimulation, "Thin" Endometrium and Previous IVF Failures
}

\author{
Natalia V. Protopopova ${ }^{1,2,3}, \mathrm{PhD}, \mathrm{ScD}$; Kseniia V. Krylova ${ }^{1}$, PGS; Elena B. Druzhinina ${ }^{1,3}$, \\ $\mathrm{PhD}$, ScD; N.V. Boldonova ${ }^{3}$, PhD; Albina V. Labygina ${ }^{2}$, PhD, ScD; V.N. Dudakova ${ }^{1}, \mathrm{PhD}$ \\ ${ }^{1}$ Russian Medical Academy of Continuous Professional Education \\ ${ }^{2}$ Scientific Centre for Family Health and Human Reproduction Problems \\ ${ }^{3}$ Irkutsk Regional Clinical Hospital, Regional Perinatal Center \\ Irkutsk, the Russian Federation
}

\begin{abstract}
The article provides an analysis of clinical, anamnestic and laboratory parameters for patients of young reproductive age who participated in IVF programs and have cryopreserved embryos. The main reasons for embryo cryopreservation were prevention of OHSS, "thin" endometrium and "previous IVF failures." It has been found that the patients from the group of transfer cancellation due to prevention of ovarian hyperstimulation had a higher ovarian reserve, a larger number of eggs, fresh and frozen embryos, and shorter shelf life of frozen embryos. All embryos were of the best quality (corresponding to the day of cultivation); the "post-thaw cultivation" technique was applied. During stimulation, lower amounts of gonadotropins were used. Patients with thin endometrium and previous IVF failures demonstrated slow growth of follicles, which required a higher course dose of gonadotropins with the addition of LH-containing preparations. Regardless of the group, in most cases, frozen/thawed embryos were transferred at the blastocyst stage (Day 5). The pregnancy rate was high in patients at risk of OHSS and with thin endometrium $(48.6 \%, 48.0 \%)$. Patients with IVF failures had a lower pregnancy rate; this is due to endometrial pathology in the medical history, a smaller number of antral follicles, oocytes, fresh and frozen embryos, and longer shelf life of frozen embryos.

(International Journal of Biomedicine. 2021;11(4):538-542.)
\end{abstract}

Key Words: assisted reproductive technologies $\bullet$ in vitro fertilization $\bullet$ vitrification • ovarian hyperstimulation syndrome

For citation: Protopopova NV, Krylova KV, Druzhinina EB, Boldonova NV, Labygina AV, Dudakova VN. Effectiveness of Cryopreservation in Patients of Young Reproductive Age with the Risk of Ovarian Hyperstimulation, "Thin" Endometrium and Previous IVF Failures. International Journal of Biomedicine. 2021;11(4):538-542. doi:10.21103/Article11(4)_OA22

\section{Abbreviations}

AMH, anti-Müllerian hormone; ART, assisted reproductive technology; FET, frozen-thawed embryo transfer; FSH, folliclestimulating hormone; hCG, human chorionic gonadotropin; IVF, in vitro fertilization; LH, luteinizing hormone; OHSS, ovarian hyperstimulation syndrome.

\section{Introduction}

According to the Register of the Russian Association for Human Reproduction, 44,000 protocols were conducted in 2018 using frozen/thawed embryos (28.1\% of the total number of assisted reproductive technology (ART) cycles in Russia), of which more than 12,000 pregnancies ended in childbirth. The pregnancy rate per cycle was $41.5 \%(39.6 \%$ in 2017), per embryo transfer - $42.4 \%(41.0 \%$ in 2017$) .{ }^{(1)}$

In cryoprotocols, the ultrafast freezing technique is used for ovarian hyperstimulation syndrome (OHSS) prevention if there are no conditions for "fresh" transfer — at "thin" 
endometrium. In addition, this technique allows preserving and using embryos at the request of a woman. ${ }^{(2-5)}$

Prognostically adverse factors of OHSS development include the following: age under 35 years, weight deficit under $25 \mathrm{~kg} / \mathrm{cm}^{2}$, enlarged ovarian size, polycystic or multifollicular structure of ovaries, pre-existing OHSS, AMH level higher than $3.6 \mathrm{ng} / \mathrm{ml}$, a great number of basal antral follicles, increased or rapidly increasing serum estradiol levels during ovarian stimulation, the use of HCG instead of progesterone to support the luteal phase after IVF, a large number of aspirated oocytes $(>20) .(6,7)$

Successful outcomes in cryoprotocols depend on many factors, and endometrial thickness is an important characteristic. There is no generally accepted approach to the definition of the "thin" endometrium in the literature. Decreased endometrial thickness in the IVF cycle is one of the indications to cryopreserve embryos: $7 \mathrm{~mm}$ or less affects the effectiveness of ART programs. ${ }^{(6,7)}$ With $8 \mathrm{~mm}$ thickness or more, one can observe high implantation and pregnancy rates. ${ }^{(6,7)}$ FET cycles are possible in a modified natural cycle, stimulated cycle, a cycle of hormone replacement therapy, and a "pure" natural cycle. $(8,9)$ In patients with thin endometrium, it is necessary to prepare endometrium using estradiol, ${ }^{(9)}$ which increases the endometrial thickness and pregnancy rates. Different culture media are used for cryotransfer. ${ }^{(10)}$ The quality of the transferred embryo is important, which is achieved by "postthaw cultivation" to the blastocyst stage. ${ }^{(11)}$

Factors that reduce the pregnancy rate in ART and cryotransfers are the age of a woman older than 36 years, obesity, surgical interventions, low AMH levels, the duration of frozen embryo storage over 12 months. ${ }^{(6,11,12)}$

The purpose of the study was to investigate the effectiveness of devitrified embryo transfers in patients at risk of OHSS, "thin" endometrium, and previous IVF failures.

\section{Materials and Methods}

To serve the study's purpose, we retrospectively analyzed 300 protocols with FET performed in 2018-2020.

Criteria for inclusion in the study were age $\leq 35$ years, tuboperitoneal infertility (N97.1), vitrified embryos available.

Exclusion criteria included a low AMH level, other infertility factors, external genital endometriosis, myoma, abnormalities of uterine development, the absence of cryopreserved embryos, male infertility, the use of any donor material (donor oocytes, sperm cells and embryos).

Depending on the cause of cryopreservation, 3 groups were formed:

Group 1 included patients $(\mathrm{n}=111)$ whose embryos were frozen to prevent OHSS development.

Group 2 included patients $(\mathrm{n}=100)$ whose embryos were cryopreserved due to "thin endometrium" in IVF program M-echo of $\leq 7 \mathrm{~mm}$.

Group 3 included patients $(\mathrm{n}=89)$ with previous IVF failures who had "extra" embryos stored after the IVF program.

In the compared groups, we studied clinical and anamnestic data, hormonal status, IVF program preceding the cryoprotocol, embryological stage, and pregnancy rate after the performed manipulations. Controlled ovarian stimulation in IVF cycles was performed under the protocol with gonadotropin-releasing hormone antagonists. The ovulation trigger was $\mathrm{hCG}$ at the dosage of 6500IU. In all cases, cryopreservation was done by vitrification using the Kitazato kit (Japan). The quality of embryos was assessed at the cleavage stage according to classification by J. Lens and coauthors. Embryos at the blastocyst stage were evaluated according to classification by D. Gardner and co-authors (1999). The thawing process was carried out pursuant to the manufacturers' recommendations. When preparing endometrium in cryoprotocol, estrogen (E2) and progesterone (P) preparations were prescribed in phases according to the day of embryo cultivation. Next, one or two excellent and good-quality embryos were transferred when the endometrial thickness (M-Echo) was $\geq 8 \mathrm{~mm}$. The effectiveness of the frozen/thawed embryo transfers was evaluated based on the pregnancy rate per embryo transfer.

Statistical processing was carried out using the STATISTICA Version 10 (StatSoft, USA). The normality of distribution of continuous variables was tested by ShapiroWilk test. For descriptive analysis, results are presented as mean \pm standard deviation (SD), median (Me), interquartile range $(\mathrm{IQR}=\mathrm{Q} 1 ; \mathrm{Q} 3)$. Multiple comparisons were performed with one-way ANOVA and Tukey's HSD Post-hoc Test. Kruskal-Wallis test was used to compare means of 3 groups of variables not normally distributed. Categorical variables were analyzed using the chi-square test with the Yates' correction. A value of $P<0.05$ was considered significant.

The study was approved by the Ethics Committee of the Scientific Center for Family Health and Human Reproduction Problems. Written informed consent was obtained from each participant.

\section{Results}

Depending on the cause of embryo cryopreservation, clinical and anamnestic characteristics have shown that the patients of the studied groups were comparable in terms of age, age at menarche, and body mass index (Table 1).

Table 1.

Clinical and anamnestic characteristics of patients

\begin{tabular}{|l|c|c|c|l|}
\hline \multirow{2}{*}{ Variable } & $\begin{array}{c}\text { Group 1 } \\
\mathrm{n}=111 \\
(1)\end{array}$ & $\begin{array}{c}\text { Group 2 } \\
\mathrm{n}=100 \\
(2)\end{array}$ & $\begin{array}{c}\text { Group 3 } \\
\mathrm{n}=89 \\
(3)\end{array}$ & \multirow{2}{*}{ Statistics } \\
\cline { 2 - 4 } & \multicolumn{2}{|c|}{$\mathrm{M} \pm \mathrm{SD} ; \mathrm{Me}(\mathrm{Q} 1 ; \mathrm{Q} 3)$} & \\
\hline \multirow{2}{*}{ Age, years } & $\begin{array}{c}31.4 \pm 3.1 \\
31.9\end{array}$ & $\begin{array}{c}31.7 \pm 2.9 \\
31.7\end{array}$ & $\begin{array}{c}31.8 \pm 2.8 \\
32.3 \\
(23 ; 35.2)\end{array}$ & $\mathrm{P}=0.5998$ \\
\hline $\begin{array}{l}\text { Age at menarche, } \\
\text { years }\end{array}$ & $\begin{array}{c}13.3 \pm 1.2 \\
13\end{array}$ & $\begin{array}{c}13.3 \pm 1.3 \\
13\end{array}$ & $\begin{array}{c}13.2 \pm 1.3 \\
13\end{array}$ & $\mathrm{P}=0.8222$ \\
$(11 ; 16)$ & $(11 ; 18)$ & $(10 ; 18)$ & \\
\hline $\begin{array}{l}\text { Body mass index, } \\
\text { kg/m }{ }^{2}\end{array}$ & $\begin{array}{c}23.2 \pm 3.8 \\
21.9\end{array}$ & $\begin{array}{c}23.2 \pm 3.9 \\
21.9\end{array}$ & $\begin{array}{c}23.7 \pm 3.9 \\
23.3\end{array}$ & $\mathrm{P}=0.5925$ \\
\hline $\begin{array}{l}\text { Pelvic inflammatory } \\
\text { diseases }\end{array}$ & $108(97.3 \%)$ & $95(95.0 \%)$ & $85(96.6 \%)$ & $\mathrm{P}=0.8724$ \\
\hline $\begin{array}{l}\text { Previous } \\
\text { reconstructive and } \\
\text { plastic fallopian } \\
\text { surgery }\end{array}$ & $70(63.1 \%)$ & $77(77.0 \%)$ & $69(77.5 \%)$ & $\mathrm{P}=0.0304$ \\
\hline
\end{tabular}


Most of them had a history of pelvic inflammatory diseases and reconstructive and plastic fallopian surgery, which caused infertility.

All patients underwent pipelle biopsy of the endometrium before IVF was planned. Histological study showed that in Group 1, the endometrium in all patients corresponded to the menstrual cycle phase, without pathology. In Group 2.19\% had a normal endometrium, 69\% had chronic endometritis, and $12 \%$ had endometrial polyps. In Group 3 with IVF failures, $29.2 \%$ had a normal endometrium, $19.1 \%$ - chronic endometritis, $37.1 \%$ - endometrial polyps, $4.5 \%$ - endometrial hyperplasia, $2 \%$ - myoma, and $4.5 \%$ had intrauterine synechiae. All patients with endometrial pathology underwent hysteroscopy, antibacterial therapy, and cyclic hormone therapy.

The analysis of laboratory and ultrasound parameters of the studied patients showed that all patients from all groups were comparable in FSH, LH levels, which were within the reference and acceptable range for IVF programs (Table 2). However, in Group 1, estradiol and AMH were significantly higher than in Groups 2 and 3.

\section{Table 2.}

Hormonal status and ultrasound data of patients before entering the IVF program

\begin{tabular}{|c|c|c|c|c|}
\hline \multirow[t]{2}{*}{ Variavle } & $\begin{array}{c}\text { Group } 1 \\
\mathrm{n}=111 \\
(1)\end{array}$ & $\begin{array}{c}\text { Group } 2 \\
\mathrm{n}=100 \\
(2)\end{array}$ & $\begin{array}{c}\text { Group } 3 \\
\mathrm{n}=89 \\
(3)\end{array}$ & \multirow[t]{2}{*}{ Statistics } \\
\hline & \multicolumn{3}{|c|}{$\mathrm{M} \pm \mathrm{SD} ; \quad \mathrm{Me}(\mathrm{Q} 1 ; \mathrm{Q} 3)$} & \\
\hline $\begin{array}{l}\text { Basal FSH, } \\
\mathrm{mlU} / \mathrm{ml}\end{array}$ & $\begin{array}{c}6.3 \pm 1.9 \\
6.3 \\
(2.6 ; 9.1)\end{array}$ & $\begin{array}{c}6.5 \pm 1.7 \\
6.4 \\
(1.6 ; 9.4)\end{array}$ & $\begin{array}{c}7.1 \pm 1.9 \\
7 \\
(2.7 ; 9.4)\end{array}$ & $\begin{array}{l}\mathrm{P}=0.0078 \\
\mathrm{P}_{1-2}=0.7093 \\
\mathrm{P}_{1-3}=0.0067 \\
\mathrm{P}_{2-3}=0.0657\end{array}$ \\
\hline $\begin{array}{l}\text { Basal LH, } \\
\mathrm{mlU} / \mathrm{ml}\end{array}$ & $\begin{array}{c}6.7 \pm 4.3 \\
6.2 \\
(2.9 ; 11.6) \\
\end{array}$ & $\begin{array}{c}5.9 \pm 3.5 \\
5.5 \\
(1.6 ; 12.8) \\
\end{array}$ & $\begin{array}{c}5.9 \pm 2.8 \\
5.4 \\
(1.3 ; 11.5) \\
\end{array}$ & $\mathrm{P}=0.1866$ \\
\hline $\begin{array}{l}\text { Basal E2, } \\
(\mathrm{pg} / \mathrm{ml}\end{array}$ & $\begin{array}{c}430.5 \pm 132.2 \\
410.2 \\
(101.7 ; 993)\end{array}$ & $\begin{array}{c}140.3 \pm 51.9 \\
113.5 \\
(51.2 ; 415)\end{array}$ & $\begin{array}{c}155.4 \pm 52.2 \\
111 \\
(90 ; 1016)\end{array}$ & $\begin{array}{l}\mathrm{P}=0.0000 \\
\mathrm{P}_{1-2}=0.0000 \\
\mathrm{P}_{1-3}=0.0000 \\
\mathrm{P}_{2-3}=0.4867\end{array}$ \\
\hline $\begin{array}{l}\text { Basal P, } \\
\mathrm{nmol} / 1\end{array}$ & $\begin{array}{c}24.5 \pm 6.3 \\
16.1 \\
(9.1 ; 160)\end{array}$ & $\begin{array}{c}30.7 \pm 6.7 \\
25.9 \\
(15.3 ; 125.2)\end{array}$ & \begin{tabular}{|c|}
$31.2 \pm 22.1$ \\
30.6 \\
$(9.2 ; 84)$
\end{tabular} & $\begin{array}{l}\mathrm{P}=0.0000 \\
\mathrm{P}_{1-2}=0.0021 \\
\mathrm{P}_{1-3}=0.0012 \\
\mathrm{P}_{2-3}=0.9635\end{array}$ \\
\hline $\begin{array}{l}\text { Basal AMH, } \\
\mathrm{ng} / \mathrm{ml}\end{array}$ & $\begin{array}{c}4.8 \pm 2.6 \\
4.1 \\
(1.6 ; 12.9)\end{array}$ & $\begin{array}{c}3.6 \pm 1.7 \\
2.4 \\
(1.7 ; 8.6)\end{array}$ & $\begin{array}{c}3.2 \pm 1.5 \\
2.3 \\
(1.8 ; 9.6)\end{array}$ & $\begin{array}{l}\mathrm{P}=0.0000 \\
\mathrm{P}_{1-2}=0.0001 \\
\mathrm{P}_{1-3}=0.0000 \\
\mathrm{P}_{2-3}=0.3687\end{array}$ \\
\hline $\begin{array}{l}\text { M-Echo endo- } \\
\text { metrial thickness, } \\
\text { mm }\end{array}$ & $\begin{array}{c}9.8 \pm 1.1 \\
10 \\
(8 ; 11)\end{array}$ & $\begin{array}{c}6.1 \pm 1.2 \\
6 \\
(5 ; 8)\end{array}$ & $\begin{array}{c}11 \pm 1.3 \\
10 \\
(8 ; 12)\end{array}$ & $\begin{array}{l}\mathrm{P}=0.0000 \\
\mathrm{P}_{1-2}=0.0000 \\
\mathrm{P}_{1-3}=0.0000 \\
\mathrm{P}_{2-3}=0.0000\end{array}$ \\
\hline $\begin{array}{l}\text { Left } \\
\text { ovary volume, } \\
\mathrm{cm}^{3}\end{array}$ & $\begin{array}{c}12.9 \pm 4.3 \\
9.6 \\
(4.9 ; 23.4)\end{array}$ & $\begin{array}{c}7.9 \pm 3.4 \\
7.3 \\
(5.8 ; 21.3)\end{array}$ & $\begin{array}{c}7.4 \pm 4.1 \\
6.7 \\
(5.9 ; 11.6)\end{array}$ & $\begin{array}{l}\mathrm{P}=0.0000 \\
\mathrm{P}_{1-2}=0.0000 \\
\mathrm{P}_{1-3}=0.0000 \\
\mathrm{P}_{2-3}=0.6619\end{array}$ \\
\hline $\begin{array}{l}\text { Right } \\
\text { ovary volume, } \\
\mathrm{cm}^{3}\end{array}$ & $\begin{array}{c}15.1 \pm 7.1 \\
10.3 \\
(5.5 ; 24.0)\end{array}$ & $\begin{array}{c}8.7 \pm 4.9 \\
8.2 \\
(5.8 ; 10.7)\end{array}$ & $\begin{array}{c}7.1 \pm 4.1 \\
6.6 \\
(5,7 ; 18.8)\end{array}$ & $\begin{array}{l}\mathrm{P}=0.0000 \\
\mathrm{P}_{1-2}=0.0000 \\
\mathrm{P}_{1-3}=0.0000 \\
\mathrm{P}_{2-3}=0.1262\end{array}$ \\
\hline $\begin{array}{l}\text { Number of antral } \\
\text { follicles }\end{array}$ & $\begin{array}{c}13.6 \pm 2.9 \\
9.0 \\
(8.5 ; 17.0)\end{array}$ & $\begin{array}{c}6.8 \pm 2.5 \\
6.5 \\
(4.5 ; 8.0)\end{array}$ & $\begin{array}{c}6.1 \pm 2.4 \\
5.5 \\
(4.5 ; 7.0)\end{array}$ & $\begin{array}{l}\mathrm{P}=0.0000 \\
\mathrm{P}_{1-2}=0.0000 \\
\mathrm{P}_{1-3}=0.0000 \\
\mathrm{P}_{2-3}=0.1622\end{array}$ \\
\hline
\end{tabular}

Group 1 showed low progesterone levels $(24.5 \pm 26.3$ $\mathrm{nmol} / \mathrm{l}$ ), which was the reason for cancelling the fresh transfer since it reduced the probability of placentation and carrying of pregnancy. ${ }^{(6,7)}$

According to ultrasound data (Table 2), Group 1 patients had more antral follicles than women in Groups 2 and 3. In Group 2, the endometrial thickness on the day before entering the IVF program was $6.1 \pm 1.2 \mathrm{~mm}$, which was the reason for cancelling embryo transfer.

In our study, we analyzed retrospectively the induced cycle preceding cryotransfer (egg collection cycle) to evaluate the stimulation profiles and gonadotropin doses (Table 3). In Group 1, FSH+LH-containing preparations were used less often in ovarian stimulation; the course dose of gonadotropin in Group 1 was lower than in Groups 2 and 3. Based on this, we concluded that in groups with "IVF failures" and "thin" endometrium, follicles were growing slower, which required the addition of LH-containing gonadotropins and a higher course dose of gonadotropins in the course of ovarian stimulation. Thus, the Group 1 patients had a better prognosis for good ovarian response in a stimulated cycle. However, in this group, higher estradiol levels on the day of transvaginal aspiration $(3161.2 \pm 1712.4 \mathrm{pg} / \mathrm{ml})$ caused the cancellation of fresh embryo transfer to prevent OHSS (Table 3).

Table 3.

Characteristics of oocyte collection cycle

\begin{tabular}{|c|c|c|c|c|}
\hline \multirow[t]{2}{*}{ Variable } & $\begin{array}{c}\text { Group } 1 \\
\mathrm{n}=111 \\
(1)\end{array}$ & $\begin{array}{c}\text { Group } 2 \\
\mathrm{n}=100 \\
(2)\end{array}$ & $\begin{array}{c}\text { Group } 3 \\
\mathrm{n}=89 \\
(3)\end{array}$ & \multirow[t]{2}{*}{ Statistics } \\
\hline & \multicolumn{3}{|c|}{$\mathrm{M} \pm \mathrm{SD} ; \mathrm{Me}(\mathrm{Q} 1 ; \mathrm{Q} 3)$} & \\
\hline $\begin{array}{l}\text { Day of menstrual } \\
\text { cycle at the start } \\
\text { of IVF stimu- } \\
\text { lation }\end{array}$ & $\begin{array}{c}3.2 \pm 1.2 \\
3(2 ; 7)\end{array}$ & $\begin{array}{c}2.78 \pm 0.9 \\
3(2 ; 5)\end{array}$ & $\begin{array}{c}2.7 \pm 0.8 \\
3(2 ; 5)\end{array}$ & $\mathrm{P}=0.7639$ \\
\hline $\begin{array}{l}\text { IVF stimulation } \\
\text { with FSH+LH } \\
\text { preparations }\end{array}$ & $63(56.8 \%)$ & $70(70.0 \%)$ & $69(77.5 \%)$ & $\mathrm{P}=0.006$ \\
\hline $\begin{array}{l}\text { Course dose of } \\
\text { gonadotropin in } \\
\text { IVF stimulation, } \\
\text { IU }\end{array}$ & $\begin{array}{c}2118.3 \pm 861.3 \\
2025 \\
(787.5 ; 5625)\end{array}$ & $\begin{array}{c}2442.2 \pm 883 \\
2250 \\
(1050 ; 5850)\end{array}$ & $\begin{array}{c}2292.9 \pm 818.7 \\
2175 \\
(1012.5 ; 4987.5)\end{array}$ & $\begin{array}{l}\mathrm{P}=0.0239 \\
\mathrm{P}_{1-2}=0.0176 \\
\mathrm{P}_{-2}=0.3252 \\
\mathrm{P}_{2-3}=0.4562\end{array}$ \\
\hline $\begin{array}{l}\text { Day of menstrual } \\
\text { cycle during fol- } \\
\text { licular aspiration }\end{array}$ & $\begin{array}{c}14.2 \pm 1.8 \\
14(10 ; 20)\end{array}$ & $\begin{array}{c}13.7 \pm 1.4 \\
14(11 ; 17)\end{array}$ & $\begin{array}{c}13.8 \pm 1.5 \\
14(11 ; 18)\end{array}$ & $\mathrm{P}=0.0544$ \\
\hline $\begin{array}{l}\text { Estradiol level } \\
\text { on the day of } \\
\text { transvaginal } \\
\text { aspiration, pg/ml }\end{array}$ & $\begin{array}{c}3161.2 \pm 1712.4 \\
2868 \\
(213 ; 6426)\end{array}$ & $\begin{array}{c}2428.2 \pm 1305 \\
2202 \\
(354 ; 6125)\end{array}$ & $\begin{array}{c}1722.8 \pm 807.2 \\
1442 \\
(3924216)\end{array}$ & $\begin{array}{l}\mathrm{P}=0.0000 \\
\mathrm{P}_{1-2}=0.0003 \\
\mathrm{P}_{1-3}=0.0000 \\
\mathrm{P}_{2-3}=0.0012\end{array}$ \\
\hline
\end{tabular}

The analysis of the embryological stage revealed that in Group 1, more follicles showed growth than in Groups 2 and 3 , and a larger number of oocytes, fresh and frozen embryos were obtained $(P<0.05)$ (Table 4$)$. The fertilization rate was high $(91.8 \%-93.4 \%)$; there was no difference in the number of embryos of good, satisfactory and low quality in all 3 groups. In Group 1, all embryos corresponded to the day of cultivation; in Groups 2 and $3-97.0 \%$ and 94.4\%, respectively (Table 4). 
Table 4.

Characteristics of the embryological stage of oocyte collection cycle

\begin{tabular}{|c|c|c|c|c|}
\hline \multirow[t]{2}{*}{ Varizble } & $\begin{array}{c}\text { Group } 1 \\
n=111 \\
(1)\end{array}$ & $\begin{array}{c}\text { Group } 2 \\
n=100 \\
(2)\end{array}$ & $\begin{array}{c}\text { Group } 3 \\
\mathrm{n}=89 \\
(3)\end{array}$ & \multirow[t]{2}{*}{ Statistics } \\
\hline & \multicolumn{3}{|c|}{$\mathrm{M} \pm \mathrm{SD} ; \mathrm{Me}(\mathrm{Q} 1 ; \mathrm{Q} 3)$} & \\
\hline $\begin{array}{l}\text { Number of aspirated } \\
\text { follicles }\end{array}$ & $\begin{array}{l}11.5 \pm 4.6 \\
11(2 ; 22)\end{array}$ & $\begin{array}{c}9.6 \pm 2.6 \\
10(5 ; 18)\end{array}$ & $\begin{array}{l}8.5 \pm 2.8 \\
8(4 ; 17)\end{array}$ & $\begin{array}{l}\mathrm{P}=0.0000 \\
\mathrm{P}_{1-2}=0.0003 \\
\mathrm{P}_{1-3}=0.0000 \\
\mathrm{P}_{2-3}=0.0831\end{array}$ \\
\hline $\begin{array}{l}\text { Number of oocytes } \\
\text { after aspiration }\end{array}$ & $\begin{array}{l}10.1 \pm 5.2 \\
10(1 ; 22)\end{array}$ & $\begin{array}{c}8.6 \pm 3.1 \\
8.5(3 ; 18)\end{array}$ & $\begin{array}{c}7.6 \pm 3 \\
7(3 ; 17)\end{array}$ & $\begin{array}{l}\mathrm{P}=0.0001 \\
\mathrm{P}_{1-2}=0.0183 \\
\mathrm{P}_{1-3}=0.0000 \\
\mathrm{P}_{2-3}=0.1987\end{array}$ \\
\hline $\begin{array}{l}\text { Number of embryos } \\
\text { after fertilization }\end{array}$ & $\begin{array}{c}7.1 \pm 4 \\
7(1 ; 19)\end{array}$ & $\begin{array}{l}6.2 \pm 2.4 \\
6(2 ; 13)\end{array}$ & $\begin{array}{l}5.8 \pm 2.3 \\
6(2 ; 14)\end{array}$ & $\begin{array}{l}\mathrm{P}=0.0089 \\
\mathrm{P}_{1-2}=0.0860 \\
\mathrm{P}_{1-3}=0.0088 \\
\mathrm{P}_{2-3}=0.6441\end{array}$ \\
\hline $\begin{array}{l}\text { Good quality } \\
\text { embryos }\end{array}$ & $45(40.5 \%)$ & $30(30.0 \%)$ & $31(34.8 \%)$ & $\mathrm{P}=0.2764$ \\
\hline $\begin{array}{l}\text { Satisfactory quality } \\
\text { embryos }\end{array}$ & $65(58.6 \%)$ & $67(67.0 \%)$ & $56(62.9 \%)$ & $\mathrm{P}=0.4480$ \\
\hline $\begin{array}{l}\text { Low quality } \\
\text { embryos }\end{array}$ & $1(0.9 \%)$ & $3(3.0 \%)$ & $2(2.3 \%)$ & $\mathrm{P}=0.8142$ \\
\hline $\begin{array}{l}\text { Embryos } \\
\text { corresponded to } \\
\text { the day of cultivation }\end{array}$ & $111(100 \%)$ & $97(97.0 \%)$ & $84(94.4 \%)$ & $\mathrm{P}=0.1307$ \\
\hline Fertilization rate & $91.8 \pm 11.9$ & $91.8 \pm 11 . ;$ & $93.4 \pm 10.5$ & $\mathrm{P}=0.5405$ \\
\hline $\begin{array}{l}\text { Number of frozen } \\
\text { embryos }\end{array}$ & $\begin{array}{l}5.1 \pm 2.9 \\
5(1 ; 16)\end{array}$ & $\begin{array}{l}3.2 \pm 1.8 \\
3(1 ; 8)\end{array}$ & $\begin{array}{l}3.1 \pm 1.8 \\
3(19)\end{array}$ & $\begin{array}{l}\mathrm{P}=0.0000 \\
\mathrm{P}_{1-2}=0.0000 \\
\mathrm{P}_{1-3}=0.0000 \\
\mathrm{P}_{2-3}=0.9509\end{array}$ \\
\hline
\end{tabular}

The analysis of frozen/thawed embryo transfers showed that in Group 2, Day 3 embryos were cryopreserved less frequently, which can be explained by the fact that in Group 2, embryos needed post-thaw cultivation more often to select embryos with good developmental potential (Table 5). Day 4 embryos were most often cryopreserved in Group 1, which is related to a large number of good-quality embryos and no need for their further selection. On Day 5 of embryo cultivation, cryopreservation was performed most often in Group 2, which indicates the worse quality of embryos in this group and the need for their selection during cultivation.

The period of frozen embryo storage in these 3 groups was also different: in Group 1, it was shorter than in Groups 2 and 3 , due to the need for additional examination and treatment of endometrial pathology, especially in Group 3 after IVF failure in the induced cycle.

The number of thawed embryos and the percentage of embryos that survived thawing was the same in all groups. The number of remaining frozen embryos in Group 1 was greater than in Groups 2 and 3, which is due to their large number at the time of freezing.

The day to day FET (i.e. without post-thaw cultivation) was conducted only in those patients whose embryos were frozen on Day 5. In Group 2, such cryotransfer was carried out most often - 57.0\% (in Groups 2 and 3, 32.4\% and $48.3 \%$ respectively). In the study groups, the blastocyst (Day 5) stage transfer was performed in $95.5 \%, 95.0 \%$, and $93.3 \%$ cases, respectively. The best pregnancy rates were in Groups 1 and 2 $(48.6 \%-48.0 \%)$, and the lowest pregnancy rate was in Group $3(32.6 \%)$.

Table 5.

Characteristics of cryopreserved embryos

\begin{tabular}{|c|c|c|c|c|}
\hline \multirow[t]{2}{*}{ Variable } & $\begin{array}{c}\text { Group } 1 \\
\mathrm{n}=111 \\
\quad(1)\end{array}$ & $\begin{array}{c}\text { Group } 2 \\
\mathrm{n}=100 \\
(2)\end{array}$ & $\begin{array}{c}\text { Group } 3 \\
n=89 \\
(3)\end{array}$ & \multirow[t]{2}{*}{ Statistics } \\
\hline & \multicolumn{3}{|c|}{$\mathrm{M} \pm \mathrm{SD} ; \mathrm{Me}(\mathrm{Q} 1 ; \mathrm{Q} 3)$} & \\
\hline $\begin{array}{l}\text { Total number of frozen } \\
\text { embryos }\end{array}$ & $\begin{array}{l}5.1 \pm 2.9 \\
5(1 ; 6)\end{array}$ & $\begin{array}{c}3.2 \pm 1.8 \\
3(1 ; 8)\end{array}$ & $\begin{array}{l}3.1 \pm 1.8 \\
3(1 ; 9)\end{array}$ & $\begin{array}{l}\mathrm{P}^{=}=0.0000 \\
\mathrm{P}_{1-2}=0.0000 \\
\mathrm{P}_{1-3}=0.0000 \\
\mathrm{P}_{2-3}=0.9509\end{array}$ \\
\hline $\begin{array}{l}\text { Freezing of } \\
\text { Day } 3 \text { embryos }\end{array}$ & $16(14.5 \%)$ & $9(9.0 \%)$ & $16(18.2 \%)$ & $\mathrm{P}=0.1920$ \\
\hline $\begin{array}{l}\text { Freezing of } \\
\text { Day } 4 \text { embryos }\end{array}$ & $59(53.6 \%)$ & $34(34.0 \%)$ & $30(34.1 \%)$ & $\mathrm{P}=0.0046$ \\
\hline $\begin{array}{l}\text { Freezing of } \\
\text { Day } 5 \text { embryos }\end{array}$ & $36(32.4 \%)$ & $57(57.0 \%)$ & $43(48.3 \%)$ & $\mathrm{P}=0,0013$ \\
\hline $\begin{array}{l}\text { Frozen embryo storage } \\
\text { period at the time of } \\
\text { thawing (months) }\end{array}$ & $\begin{array}{l}5.8 \pm 1.8 \\
2(1 ; 12)\end{array}$ & $\begin{array}{c}9.4 \pm 2.1 \\
5.5(1 ; 32)\end{array}$ & $\begin{array}{l}9.5 \pm 1.7 \\
5(1 ; 46)\end{array}$ & $\begin{array}{l}\mathrm{P}=0.0000 \\
\mathrm{P}_{1-2}=0.0000 \\
\mathrm{P}_{1-3}=0.0000 \\
\mathrm{P}_{2-3}=0.9291\end{array}$ \\
\hline $\begin{array}{l}\text { Number of women } \\
\text { who have frozen embryos } \\
\text { after transfer }\end{array}$ & $57(51.4 \%)$ & $34(34.0 \%)$ & $27(30.3 \%)$ & $\mathrm{P}=0.0042$ \\
\hline $\begin{array}{l}\text { Number of remaining } \\
\text { frozen embryos }\end{array}$ & $\begin{array}{l}4.3 \pm 2.4 \\
3(1 ; 12)\end{array}$ & $\begin{array}{l}2.6 \pm 1 \\
2(1 ; 6)\end{array}$ & $\begin{array}{l}3 \pm 1.8 \\
3(1 ; 8)\end{array}$ & $\begin{array}{l}\mathrm{P}=0.0000 \\
\mathrm{P}_{1-2}=0.0000 \\
\mathrm{P}_{1-3}=0.0000 \\
\mathrm{P}_{2-3}=0.3006\end{array}$ \\
\hline $\begin{array}{l}\text { «Day to day» } \\
\text { cryotransfer }\end{array}$ & $36(32.4 \%)$ & $57(57.0 \%)$ & $43(48.3 \%)$ & $\mathrm{P}=0.0013$ \\
\hline $\begin{array}{l}\text { Post-thaw cultivation } \\
\text { of embryos }\end{array}$ & $70(63.1 \%)$ & $38(38.0 \%)$ & $40(44.9 \%)$ & $\mathrm{P}=0.0008$ \\
\hline $\begin{array}{l}\text { Transfer of cryopreserved } \\
\text { Day } 4 \text { embryos (morula) }\end{array}$ & $5(4.5 \%)$ & $4(4.0 \%)$ & $6(6.7 \%)$ & $\mathrm{P}=0.6584$ \\
\hline $\begin{array}{l}\text { Transfer of cryopreserved } \\
\text { Day } 5 \text { embryos } \\
\text { (blastocyst) }\end{array}$ & $106(95.5 \%)$ & $95(95.0 \%$ & $83(93.3 \%)$ & $\mathrm{P}=0.770$ \\
\hline Pregnancy rate & $54(48.6 \%)$ & $48(48.0 \%)$ & $29(32.6 \%)$ & $\mathrm{P}=0.0423$ \\
\hline
\end{tabular}

\section{Conclusion}

The retrospective analysis of clinical, anamnestic and laboratory parameters in IVF patients with cryopreserved embryos revealed that the patients from the group of transfer cancellation due to OHSS prevention had a higher ovarian reserve, a larger number of eggs and fresh and frozen embryos, and shorter shelf life of frozen embryos. All embryos were of the best quality. During stimulation, lower amounts of gonadotropins were used. 
Patients with a thin endometrium and previous IVF failures demonstrated slow growth of follicles, which required a higher course dose of gonadotropins with the addition of LH-containing preparations.

Regardless of the group, in most cases, frozen/thawed embryos were transferred at the blastocyst stage. The pregnancy rate was high in patients at OHSS risk and with a thin endometrium, which tops the figures for the Russian Federation $(42.4 \%$ in $2018 ; 41.0 \%$ in 2017). Patients with IVF failure $(32.6 \%)$ had a lower pregnancy rate; this is due to endometrial pathology in the medical history, a smaller number of antral follicles, oocytes, fresh and frozen embryos, and longer shelf life of frozen embryos.

\section{Acknowledgments}

This article contains material that has been discussed at the VIII International Research and Practical Conference «FUNDAMENTAL AND APPLIED ASPECTS OF REPRODUCTION» (December 2021, Irkutsk, Russia). The author thanks all researchers who participated in the oral discussion.

\section{Conflict of Interests}

The authors declare that they have no conflicts of interest.

\section{References}

1. Register ART 2018. Available from: https://rahr.ru/d registr_otchet/RegistrART2018.pdf

2. Maheshwari A, Pandey S, Amalraj Raja E, Shetty A, Hamilton M, Bhattacharya S. Is frozen embryo transfer better for mothers and babies? Can cumulative meta-analysis provide a definitive answer? Hum Reprod Update. 2018 Jan 1;24(1):35-58. doi: 10.1093/humupd/dmx031.

3. Roque M, Haahr T, Geber S, Esteves SC, Humaidan P. Fresh versus elective frozen embryo transfer in IVF/ICSI

*Corresponding author: Albina V. Labygina, PhD, ScD. Scientific Centre for Family Health and Human Reproduction Problems, Irkutsk, the Russian Federation.E-mail.albinalab2212@mail.ru cycles: a systematic review and meta-analysis of reproductive outcomes. Hum Reprod Update. 2019 Jan 1;25(1):2-14. doi: 10.1093/humupd/dmy033.

4. Roque M, Esteves SC. Elective frozen embryo transfer (freeze-all): there seems to be no harm to transfer in the next immediate menstrual cycle. Ann Transl Med. 2020 Aug;8(15):913. doi: 10.21037/atm-20-2070.

5. Blockeel C, Drakopoulos P, Santos-Ribeiro S, Polyzos NP, Tournaye H. A fresh look at the freeze-all protocol: a SWOT analysis. Hum Reprod. 2016 Mar;31(3):491-7. doi: 10.1093/humrep/dev339.

6. Beik EP, Syrkasheva AG, Dolgushina NV. [Effectiveness of programs of auxiliary reproductive technologies in patients of late reproductive age]. Gynecology. 2018; 20 (1): 109-12. doi: 10.26442/2079-5696 20.1.109-112. [Article in Russian]. 7. Humaidan P, Nelson SM, Devroey P, Coddington CC, Schwartz LB, Gordon K, Frattarelli JL, Tarlatzis BC, Fatemi HM, Lutjen P, Stegmann BJ. Ovarian hyperstimulation syndrome: review and new classification criteria for reporting in clinical trials. Hum Reprod. 2016 Sep;31(9):1997-2004. doi: 10.1093/humrep/dew149.

8. Lawrenz B, Coughlan C, Melado L, Fatemi HM. The ART of frozen embryo transfer: back to nature! Gynecol Endocrinol. 2020 Jun;36(6):479-483. doi: 10.1080/09513590.2020.1740918.

9. Koloda YuA, Anshina MB. [The use of estradiol hemihydrate transdermal gel in frozen embryo transfer cycles (an open multicenter non-intervention study)]. Russian Journal of Human Reproduction. 2019;25(6):51-57. doi: 10.17116/ repro20192506151. [Article in Russian].

10. Protopopova NV, Druzhinina EB, Krylova KV, Mylnikova YV, Dvoryanov JA, Labygina AV, Kovalenko II. [Analysis of efficiency of application of media with hyaluronic acid in cryoprotocols]. Gynecology. 2020; 22 (2): 26-29. doi: 10.264 42/20795696.2020.2.190710. [Article in Russian].

11. Protopopova NV, Druzhinina EB, Mylnikova YV, Boldonova NA, Dvoryanov JA, Krylova KV, Labygina AV, Kovalenko II. [Efficiency of cryoperenosis depending on various factors]. Gynecology. 2018;20(5):59-62. doi: 10.26442/2079-5696_2018.5.59-62. [Article in Russian].

12. Protopopova NV, Druzhinina EB, Boldonova NA, Labygina AV, Mylnikova YV, Sakhyanova NL, Maschakevich LI, Krylova KV, Kurashova NA. The Effectiveness of In Vitro Fertilization Programs in Patients with Low Anti-Müllerian Hormone Levels. International Journal of Biomedicine. 2020;10(2):112-115. doi: 10.21103/Article10(2)_OA4. 